\title{
Molecular Identification of Phytophagous Scarabaeid from different regions of India
}

\author{
K. Srinivasa Murthy
}

National Bureau of Agricultural Insect Resources, P B No.2491, H.A.Farm Post, Bellary Road, Bangalore - 560 024, Karnataka, India

\begin{abstract}
Identification of scarabaeid beetles is a challenging task due to variable morphological differences among species and delineation among the immature forms, the grubs and adults. A method for easy and accurate species-level identification at any life stage is required. In this study, a 658-base pair region of the mitochondrial cytochrome oxidase I (COI) gene was used to explore its utility in the identification of important beetles. Twenty seven specimens were collected from 25 locations in different states, were characterized using specific primers for their identification. Sequence analysis and divergence among the species was assessed. The composition of the mitochondrial sequence of the COI gene in the present study was expectedly AT biased. Genbank accession numbers were obtained for the species. Molecular sequence information from NCBI revealed relatedness in all the collected scarabaeids, accurately as revealed by their morphological characters. The studies indicate the relevance of DNA sequencing to match different forms of beetles and address ambiguities in morphological identification and information on species diversity would help plan strategies for pest management.
\end{abstract}

Keywords-Beetle, Characterisation, COI gene, Scarabaeid, Sequence.

\section{INTRODUCTION}

Scarab beetles are the most diverse and widely distributed insects which belong to the largest order Coleoptera. The family Scarabaeidae is composed of about $91 \%$ of all scarabaeoids and represented by 30,000 species worldwide (Pathania et.al., 2015). About 2500 species are reported from India (Chandra and Gupta, 2011) and a majority of these are phytophagous (sub families Melolonthinae, Rutelinae,Dynastiae and Cetoniinae) (Ali, 2000., Dadmal et.al., 2013). The adult beetles and their grubs cause extensive damage to fruit crops, vegetables, ornamental plants, plantation crops pastures, turf and meadow grasses, lawns, golf courses and forest trees (Dashad et.al., 2008 .,Lawerence et.al., 2013). Adults of the sub-family Melolonthinae and Rutelinae are predominantly leaf feeders where as those of Cetoniinae feed on flowers and fruits, and are popularly referred to as flower beetles, prefer nectar, sap or juice of ripening fruits and vegetables. Members of Dynastinae usually attack stems or roots of plants (Bhat et.al., 2005). Grubs of Melolonthinae, Rutelinae and Dynastinae commonly referred to as white grubs are often soil dwelling and cause extensive damage to the roots of cereals, legumes, small fruit plants, shrubs and trees (Thakre and Zade, 2012). In India, the white grubs are pests of national importance (Chandra and Ahirwar, 2007., Chandra and Singh, 2010).

Lack of taxonomic understanding has been a major impediment to the study and management of scarabaeid beetles. Identification of scarabaeid species is a challenging task due to variable morphological differences among species and delineation among the immature forms, the grubs and adults. Species identification of larval specimens requires a sophisticated technique and also vast knowledge of the cephalopharyngeal skeleton morphology (Greenberg, 2002).

Morphological identification keys are often effective only for a particular life stage or gender (Hebert et.al.,2003., Chandra and Gupta, 2012., Gupta et.al., 2014.,). The use of taxonomic keys often requires proficiency to avoid inaccuracy for those similarities which cannot be easily deciphered. Under these circumstances, DNA analysis appears promising to solve the species identification problem owing to the durability and stability of the DNA 
(Wallman and Donnellan, 2001). It also can solve the problems of morphological identification with damaged specimens (Judith and Nicola, 2008). This technique is based on the mitochondrial DNA (mtDNA) encoded cytochrome oxidase I gene (COI) (Wells and Sperling ,2001., Sharma et.al., 2004, Theurkar et.al., 2013). Partial sequences of this COI gene have been shown to have sufficient discrimination power (Stijn and Matthias, 2009., Zahoor et.al., 2013), which makes it suitable for a diagnostic taxonomy. The COI gene has been used for inferring phenogram analysis at various taxonomic levels of many animal groups (Avise,2000). Efficient Mitochondrial DNA (mtDNA) -COI based methods in the delineation and identification of scarabaeid species have been reported (Blaxter et.al., 2004., Dittrich et.al., 2009, Dirk et.al., 2007, Dirk et.al., 2011, Tauz et.al., 2003, Fang, 2009., Paul et.al, 2009).

\section{MATERIALS AND METHODS}

\section{Field survey and Collection of Scarabaeid Beetles:}

The diversity of scarab beetles depends on the availability of food for larvae and adult, weather conditions and soil type. Collection of scarab beetles was made randomly by hand picking and light trapping. Grubs were collected from a soil depth of 0.25-0.05 $\mathrm{m}$ depth in cultivated fields. The beetles were collected during MayJune which is the major activity period to assess the diversity. The populations were collected from different states and geographical locations of the country from various trees and crop plants (arecanut, coconut, groundnut, mulberry, millets, neem, soybean, sugarcane and vegetables).

\section{Collection of Adult Beetles Using Light Traps:}

Light traps were used for four months (May - September) to collect the beetle populations. The light traps were placed in the center of the fields at a height of about 3 meters above the ground and operated between 7:00 PM to 5:00 AM to attract the scarabaeid beetles which are positively heliotactic in nature. The light trap comprised of PVC plastic funnel of $25 \mathrm{~cm}$ in height, and $30 \mathrm{~cm}$. diameter. The bottom diameter of the funnel was $5 \mathrm{~cm}$. The rain shed cone for protecting the bulb was fixed at $17 \mathrm{~cm}$ above the funnel with the help of three white metal sheets. The diameter of the rain shed cone was $20 \mathrm{~cm}$. The light source consisted of a 125-watt incandescent light bulb with copper wire choke. The light trap had three baffles $(30 \mathrm{~cm} \mathrm{x}$
$10 \mathrm{~cm}$ ), placed at a uniform distance of $10 \mathrm{~cm}$ around the circumference of funnel. The baffles were fixed to emit light uniformly in all directions without any interference, when the beetles are attracted to light they collide with baffles and fall into the trap. A nylon bag was attached to the bottom of this funnel for collection of beetles. The collected beetles were preserved in a vial containing $70 \%$ alcohol and taken to the laboratory for morphological identification and a few samples stored at $-80^{\circ} \mathrm{C}$ at the Division of Genomic Resources, ICAR-NBAIR, India for characterization and identification.

\section{Identification of the Beetles:}

The scarab adults and grubs collected from different locations were identified up to the genus level at the Department of Entomology, University of Agricultural Sciences, Bangalore and the Division of Entomology, Indian Agricultural Research Institute, New Delhi, based on the keys and characters listed by (Dirk, et.al., 2011). Adult beetles were identified based on the morphological characters such as body size, coloration, surface sculpture and male genitalia, while the grubs were differentiated based on the color, size of the cephalic capsule, number and form of dorsal sensorial maculae of the last antennomere, distribution, stimulatory structures in the maxilla and mandible, raster pattern arrangement of bristles and hairs on the underside of the abdomen, shape of anal slit (crescent, $Y$ shaped, strongly Y shaped), shape and size of the respiratory plates, proportions of each pair of legs and tarsungulus size (Dashad et.al, 2008, Dirk et.al, 2011).

\section{Extraction of Genomic DNA:}

Total genomic DNA was isolated using the method described by (Gavarāne et.al, 2011) . Genomic DNA was isolated using modified Qiagen DNeasy blood tissue kit method. The insects were washed thoroughly in double distilled water. Total genomic DNA was isolated from the leg portion of the insect. The cleaned insect leg portion was homogenized in $1.5 \mathrm{ml}$ appendorf tube in $500 \mu \mathrm{l}$ of TE (Tris-EDTA-pH 8), with hand pestle and the homogenate was centrifuged at $10,000 \mathrm{rpm}$ for 10 minutes in cooling centrifuge (-40C). The supernatant was discarded and the pellet was dissolved in $500 \mu \mathrm{l}$ of lysis buffer $(400 \mu \mathrm{l}$ of TE and $100 \mu \mathrm{l}$ of $5 \%$ SDS), followed by the addition of 6 $\mu l$ of Proteinase $\mathrm{K}$, and the solution was incubated at $650 \mathrm{C}$ for one and half hours. A mixture of $120 \mu \mathrm{l}$ phenol 
chloroform isomyl alcohol (25:24:1) was added and the tubes vortexed for 30 seconds and then centrifuged for 10 minutes at 10,000 rpm in cooling centrifuge. The upper aqueous layer was carefully transferred in to fresh tube, without disturbing the protein layer at the interphase. Isopraponal $(500 \mu \mathrm{l})$ was added to this aqueous layer and stored at $-40 \mathrm{C}$ overnight and then centrifuged at $7000 \mathrm{rpm}$ for 10 minutes. The supernatant was discarded and the pellet was washed with $70 \%$ alcohol and later the acohol was drained out, the pellet was dried and dissolved in $30 \mu \mathrm{l}$ of TE-I was stored at -200C after checking on $0.8 \%$ agarose gel and visualized after staining with ethidum bromide.

\section{DNA Quantification- PCR amplification and sequencing of COI gene fragment:}

The isolated DNA samples were quantified in order to find out the amount of DNA using Nanodrop Spectrophotometer. The absorption was measured at $260 \mathrm{~nm}$ as the nitrogenous bases in DNA show strong absorption at this wavelength.

The extracted DNA samples were subjected to PCR amplification of $658 \mathrm{bp}$ cytochromeoxidase I (COI) gene fragment. The amplification was carried out using the universal CO I primers: COI forward (LCO1490) 5'GGTCAACAAATCATAAAGATATTGG 3'and CO I reverse

(HCO2198) 5'TAACTTCAGGCTGACCAAAAAATCA 3' obtained from M/S Bioserve biotechnologies (India) Pvt Ltd. Amplification was performed in $0.2 \mathrm{ml}$ PCR tubes with total volume of $25 \mu 1$ containing $2.5 \mu 1$ of template DNA, $4 \mu 1$ of GeNeiTM 10X Taq buffer containing $15 \mathrm{mM}$ of $\mathrm{MgCl}, 2.5$ $\mu \mathrm{l}$ of GeNieTM $10 \mathrm{mM}$ dNTP mix, $1 \mu$ of forward primer (10pmol $/ \mu \mathrm{l}), 1 \mu \mathrm{l}$ of reverse primer $(10 \mathrm{pmol} / \mu \mathrm{l}), 1 \mu \mathrm{l}$ of GeNieTM Taq DNA polymerase and $13 \mu 1$ of sterile water. Temperature conditions for amplification were as follows: initial denaturation at $95^{\circ} \mathrm{C}$ for 2 minutes, denaturation at $95^{\circ} \mathrm{C}$ for 30 seconds, annealing at $50^{\circ} \mathrm{C}$ for 1 minute, extension at $72^{\circ} \mathrm{C}$ for 2 minutes followed by 34 cycles and final extension at $72^{\circ} \mathrm{C}$ for 7 minutes were carried out in thermal- cycler (BioRad, USA). PCR-amplified products were purified using Bioneer's PCR purification Kit (www.Bioneer.com). Amplification of DNA was then checked by running the samples on $1 \%$ agarose gel using 250bp DNA ladder and visualized in gel dock. The amplified products were then sent to commercial sequencing at M/S. Eurofins Pvt Ltd, Bangalore where the chain termination method was used for sequencing.

\section{Sequence analysis and data interpretation:}

The most commonly used method of DNA sequencing is the dideoxy method or chain termination method. The amplified products of COI gene were got sequenced at M/s. Eurofin Pvt Ltd, Bangalore. The COI gene sequence data was retrieved in the form of Chromatograms. Several individuals from each species were sequenced and chromatograms were subjected to VSQual (Binneck et.al., 2004) to evaluate the reliability of the data, and good quality fragments were used to construct a consensus sequence for each sample. Chromatograms were edited to discard ambiguous bases, and edited sequences were aligned by using the Basic Local Alignment Search Tool (BLAST), with the sequences of same or related genera retrieved from the nucleotide database (PUBMED) of National Centre for Biotechnology Information (NCBI). The sequence data's was submitted to NCBI and accession numbers were obtained. Consensus sequences of COI partial gene were multiple aligned using Clustal W (ver. 1.83) (Thompson et.al., 1994., Tauz et.al, 2003).

\section{RESULTS AND DISCUSSION}

\section{Molecular identification:}

The genomic DNA was isolated from the populations of scarabaeids collected from different states viz, Andhra pradesh, Himachal Pradesh, Karnataka, Kerala, Meghalaya, Tamilnadu and Uttar Pradesh. Persusal of the data on the collection of scarabaeid beetles from the different geographical locations and crops and their identification had revealed the diversity of beetles in the country. An array of phytophagous beetles (Table 1) belonging to the subfamilies (Cetoniinae, Dynastinae, Melolonthinae and Rutelinae) were collected

In the present studies, the isolated genomic DNA of scarab beetles from various locations was characterised through COI gene fragment (648-656 bp size) was successfully sequenced for all the specimens, and the alignment of all specimens considered in this study lacked any insertion or deletion. A total of 27 species were sequenced over COI regions and the Blast done with NCBI database to decipher the identity of the scarabaeids from 
various locations is given in Table 1. Molecular sequence information from NCBI revealed relatedness in all the collected scarabaeids, accurately as revealed by their morphological characters. Our observations, corroborate with the reports of (Dittrich et.al., 2006, Zahur et.al., 2013, Wardani and Sugiyarto, 2009).

The utility of DNA data in taxonomy and species diagnosis in the scarabaeid beetles was reported by (Dirk et.al., 2007 and 2011), based on the sequence variation in DNA based groups which highly structured. The population of scarabaeids from various locations were characterised using Cytochrome $\mathrm{C}$ oxidase subunit I (COI) gene, which has been recognised as an effective marker not only for species identification but also for phylogenetic relationship (Hebert et al., 2003, Dhoj et.al., 2009, Maryati and Sugiyato, 2009, Imura et al., 2014).

\section{Nucleotide Analysis:}

Nucleotide analysis of the sequences was carried out in order to find out the MCL (Maximum Composite Likelihood) estimate of the pattern of nucleotide substitution, $\mathrm{AT} \%, \mathrm{GC} \%$ and the AT content at first, second and third codon position. The MCL pattern showed the probability of substitution (r) from one base (row) to another base (column) (Khannal et.al., 2012). The sum of $\mathrm{r}$ values was made equal to 100 . Rates of different transitional are shown in substitutions which were 18.79 , 21.13, 9.83 and 8.97 and the transversionsal substitutions are given in (Table 2). The nucleotide frequencies are $27.99 \%(\mathrm{~A}), 40.02 \%(\mathrm{~T} / \mathrm{U}), 18.63 \%(\mathrm{C})$, and $13.36 \%(\mathrm{G})$. The transition/ transversion rate ratios are $\mathrm{k} 1=3.253$ (purines) and $\mathrm{k} 2=2.558$ (pyrimidines). The overall transition/ transversion bias is $\mathrm{R}=1.288$, where $\mathrm{R}=$ $\left[A * G^{*} k 1+T * C * k 2\right] /[(A+G) *(T+C)$.

The analysis also revealed that the percentage of AT was comparatively more i.e., $33.25 \%$ ranging between $29.8-34.9 \%$ than that of GC which is $16.8 \%$ with a minimum of $15.1 \%$ and maximum of $19.4 \%$. indicating that the sequences were AT biased. This difference was attributed to the AT percentage at different codon position. The AT content at first codon position ranged between46$48 \%$ withaverageof $44 \%$, andtheATpercentage at second and third codon position is nearly invariant $27 \%$ and $28 \%$ respectively.
The composition of the mitochondrial sequence of the COI gene in the present study was expectedly AT biased and this was generally observed in several previous studies (Williams et.al.,, 1990). In general, the frequency of transitional substitutions is known to be higher than transversion substitutions in the genome (Tauz et.al, 2003), According to $10 \mathrm{X}$ rule the percentage of nucleotide divergence between the intraspecies should be less than $3 \%$ and that of interspecies should be more than 3\%. Hence the sequences analyzed in the present study exhibited high inter species variability on the basis of nucleotide sequences. Therefore, the intra specific divergence was higher enough to discriminate between the individuals.

Results indicated that the COI-based pest identification was extremely effective for the beetles based on the COI marker profile. DNA sequence data have been employed successfully to elucidate the relationships of many groups of insect species at generic level. Molecular sequence information from NCBI revealed relatedness in all the collected scarabaeids, accurately as revealed by their morphological characters. Our observations, corroborate with the reports of (Richards et.al, 1997., Zhu et.al., 2000, Blaxter et.al., 2004.,Monti et.al, 2005). Qiu , et.al, (2009), suggested that where sequence information is available in Genbank for morphologically defined species, which can be matched with some DNA based clusters, close relationship can be identified readily in sequence variation in field collected field samples and these clusters are likely to correspond to previously described unknown species. Mgocheki et.al.,(2012), reported that the sequence information based on mitochondrial markers can be utilized for species delineation of adults and grubs of scarabaeids inferring larval taxonomy. Our studies indicate the relevance of DNA sequencing to match different forms of scarabs and address the issues of having to depend exclusively on morphological features and avoid misdiagnosis.

The species diversity is influenced by the cropping pattern, the climatological factors and the altitude. The abundance was reported to be negatively and significantly correlated with altitude. Low temperatures at higher altitudes inhibit the growth and development of beetles (Dhoj et.al., 2009., Khanal et.al., 2012) .

Our findings contribute to a better understanding of the identification of pests by COI genes and aid in formulating better management strategies. 


\section{CONCLUSIONS}

The diversity of phytophagous scarabaeid beetles from various geographical locations of India occurring in crops were morphologically identified and characterised using molecular tools, Molecular sequence information from NCBI revealed relatedness in all the collected scarabaeids, accurately as revealed by their morphological characters. Phylogenetic tree revealed the genetic relatedness among the beetles and understand the evolutionary relationship. The relevance of DNA sequencing to match different forms of beetles and address limitations in morphological identification is indicated. Knowledge on species diversity, through surveys would be helpful in planning strategies for conservation of natural enemies, habitat management, design and develop pest management strategies.

Table 1. Scarabaeid beetles collected from various locations and their accession numbers

\begin{tabular}{|c|c|c|c|c|c|}
\hline Sl.No & Species & Subfamily & Location & Latitude/Longitude & Acc.No. \\
\hline \multirow[t]{3}{*}{1} & \multirow{3}{*}{ Holotrichia consanguinea } & \multirow{17}{*}{ Melolonthinae } & Anakapalle & $17.38^{0} \mathrm{~N}, 83.2^{0} \mathrm{E}$ & KU35553 \\
\hline & & & Samarlakota & $17.5^{0} \mathrm{~N}, 82.2^{0} \mathrm{E}$ & KU35552 \\
\hline & & & Tirupathi & $13.65^{0} \mathrm{~N}, 79.42^{0} \mathrm{E}$ & \\
\hline 2 & Holotrichia serrata & & Bangalore & $12.97^{0}$ N., $77.57^{0} \mathrm{E}$ & KT254245 \\
\hline 3 & Schizonycha sp. & & Shimoga & $13.92^{\circ} \mathrm{N}, 75.56^{\circ} \mathrm{E}$ & 1762749 \\
\hline \multirow[t]{2}{*}{4} & \multirow[t]{2}{*}{ Maladera insanabilis } & & \multirow[t]{2}{*}{ Phasighat } & \multirow[t]{2}{*}{$25.34 .11^{\circ} \mathrm{N}, 91^{\circ} 59.2 \mathrm{E}$} & KU35551 \\
\hline & & & & & KU35551 \\
\hline 5 & Apogonia sp. & & Aligarh (UP) & $27.89^{\circ} \mathrm{N}, 78.08^{\circ} \mathrm{E}$ & 1762764 \\
\hline \multirow[t]{5}{*}{6} & \multirow{5}{*}{ Leucopholis lepidophora } & & Sringeri & \multirow{5}{*}{$\begin{array}{l}12.57-13.52^{0} \mathrm{~N} . \\
75.72-75.22^{0} \mathrm{E} \\
14.6196^{\circ} \mathrm{N}, 74.84^{\circ} \mathrm{E}\end{array}$} & KU665428 \\
\hline & & & Shivamoga & & KU665428 \\
\hline & & & Thirtahalli & & KU665428 \\
\hline & & & Sirsi & & KU665428 \\
\hline & & & $\begin{array}{l}\text { Sultan Betheri } \\
\text { (Kerala) }\end{array}$ & & KU665428 \\
\hline \multirow[t]{3}{*}{7} & \multirow[t]{3}{*}{ Leucopholis burmeisteri } & & Chikmagalur & $13.40^{0}$ N., $78.05^{0} \mathrm{E}$ & KU665432 \\
\hline & & & Belgaum & $15.51^{0} \mathrm{~N} ., 74.29^{0} \mathrm{E}$ & KU665432 \\
\hline & & & $\begin{array}{l}\text { Kannur } \\
\text { (Kerala) }\end{array}$ & $11.8^{0} \mathrm{~N}, 75.32^{0} \mathrm{E}$ & KU665432 \\
\hline 8 & Leucopholis coneophora & & Thrissur & $10.52^{0} \mathrm{~N}, 76.2^{0} \mathrm{E}$ & KU665428 \\
\hline 9 & Heterorrhina sp. & \multirow{2}{*}{ Cetoninae } & $\operatorname{Ooty}(\mathrm{TN})$ & $11.41^{0} \mathrm{~N} ., 70.58^{0} \mathrm{E}$ & KM657485 \\
\hline 10 & Protaetia sp. & & Tirupathi (AP) & & KM657490 \\
\hline
\end{tabular}




\begin{tabular}{|c|c|c|c|c|c|}
\hline & & & Phasighat & $28.069^{\circ} \mathrm{N}, 95.32^{\circ} \mathrm{E}$ & KT1762766 \\
\hline & & & Shillong & $25.34 .11^{\circ} \mathrm{N}, 91^{\circ} 59.2 \mathrm{E}$ & KM657489 \\
\hline & & & Ooty $(\mathrm{TN})$ & $11.41^{0} \mathrm{~N} ., 70.58^{0} \mathrm{E}$ & KM657486 \\
\hline & & & Gudalur & $11.59^{0} \mathrm{~N} ., 76.50^{0} \mathrm{E}$ & KT1762776 \\
\hline & & & & & 1762777 \\
\hline 11 & Protaetia cuprea ignicollis & & Bangalore & $12.97^{0}$ N., $77.57^{0} \mathrm{E}$ & KT203778 \\
\hline 12 & Adoretus cupreus & & Anand & $22.56^{\circ} \mathrm{N}, 72.92^{\circ} \mathrm{E}$ & KT254249 \\
\hline 13 & Adoretus falvus & Rutelinae & (Gujarat) & & KT254250 \\
\hline 14 & Anomala sp. & & Shimla (HP) & $31.18^{\circ} \mathrm{N}, 77.17^{\circ} \mathrm{E}$ & 1762765 \\
\hline & & & $\begin{array}{l}\text { Bangalore } \\
\text { (Dasarahalli) }\end{array}$ & $12.97^{0}$ N., $77.57^{0} \mathrm{E}$ & KM657492 \\
\hline & & & & $25.34 .11^{\circ} \mathrm{N}, 91^{\circ} 59.2 \mathrm{E}$ & KM657491 \\
\hline 15 & Anomala ruficapilla & & $\begin{array}{l}\text { Bangalore } \\
\text { (Dasarahalli), }\end{array}$ & $12.97^{0}$ N., $77.57^{0} \mathrm{E}$ & KT254246 \\
\hline 16 & Anomala dimidata & & Theni & & KU517668 \\
\hline & Anomala dimidata & & $\begin{array}{l}\text { Theni } \\
\text { (Tamilnadu) }\end{array}$ & $15.51^{0} \mathrm{~N} ., 77.79^{0} \mathrm{E}$ & KU517664 \\
\hline 17 & Phyllopertha horticola & & $\begin{array}{l}\text { Anekal } \\
\text { (Tamilnadu) }\end{array}$ & $12.70^{\circ} \mathrm{N}, 77.69^{\circ} \mathrm{E}$ & KT203779 \\
\hline 18 & Exomala pallidipennis & & Bangalore & & KU317746 \\
\hline & & & Valampari (T.N) & $15.51^{0}$ N.,74.29 $\mathrm{E}$ & KT203780 \\
\hline 19 & Onthonhagus nuchicornis & Scarghoeinge & Chintamani & $13^{\circ} 24^{0} \mathrm{~N} 78^{\circ} 04^{\prime} 12 . \mathrm{E}$ & KU517667 \\
\hline & & Dcaranaemae & Bangalore & & KU517666 \\
\hline 20 & Onth on a n at & & Mudhigeri & $13.1365^{\circ} \mathrm{N}, 75.64^{\circ} \mathrm{E}$ & KU665401 \\
\hline & 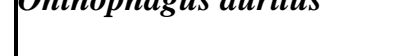 & & Mudhigeri & & KU665398 \\
\hline 21 & Onthophagus coenobita & & $\begin{array}{l}\text { Bangalore } \\
\text { (Nandi hills) }\end{array}$ & $13.3702^{\circ} \mathrm{N}, 77.68^{\circ} \mathrm{E}$ & KU665397 \\
\hline 22 & Copris tripartitus & & \begin{tabular}{|l} 
Bangalore \\
(Nandi Hills)
\end{tabular} & $13.3702^{\circ} \mathrm{N}, 77.68^{\circ} \mathrm{E}$ & KU665396 \\
\hline 23 & Basilepta sp & & Mudhigeri & $13.1365^{\circ} \mathrm{N}, 75.64^{\circ} \mathrm{E}$ & KU665400 \\
\hline
\end{tabular}




\begin{tabular}{|c|c|c|c|c|c|}
\hline 24 & Calicnemis obesa & \multirow{3}{*}{ Dynastinae } & Theni & $15.51^{0} \mathrm{~N} ., 77.79^{0} \mathrm{E}$ & KU517665 \\
\hline 25 & Oryctes rhinoceros & & Theni (TN) & $15.51^{0}$ N., $77.79^{0} \mathrm{E}$ & KU517993 \\
\hline 26 & Alissonotum sp & & Kapatganj (UP) & $26.920^{\circ} \mathrm{N}, 83.77^{\circ} \mathrm{E}$ & 1762754 \\
\hline 27 & Aethina concolor & Nitidulinae & Mudhigeri & $13.1365^{\circ} \mathrm{N}, 75.64^{\circ} \mathrm{E}$ & KU665399 \\
\hline
\end{tabular}

Table 2. Maximum Composite Likelihood estimate of the pattern of nucleotide substitution of COI

\begin{tabular}{|l|l|l|l|l|}
\hline & A & T & C & G \\
\hline $\mathbf{A}$ & ----- & 8.26 & 3.84 & 8.97 \\
\hline $\mathbf{T}$ & 5.78 & --- & 9.83 & 2.76 \\
\hline $\mathbf{C}$ & 5.78 & 21.13 & ---- & 2.76 \\
\hline $\mathbf{G}$ & 18.79 & 8.26 & 3.84 & ---- \\
\hline
\end{tabular}

\section{ACKNOWLEDGEMENTS}

The authors are thankful to the Director, ICARNBAIR, for providing the facilities. Identification of the scarabaeids by Dr. K. Sreedevi, ICAR - NBAIR and Dr. ARV Kumar Department of Entomology, GKVK , Bangalore is duly acknowledged. We also thank Dr. Veena kumari, Dr. A.N.Shylesha, Dr. Mahendirn and Dr. Jagdish Patil of ICAR -NBAIR for the collections.

\section{REFERENCES}

[1] Ali, A.T.M . (2001). Biosystematics of phytophagous scarabaeidae-An Indian Overview. In: Indian Phytophagous Scarabs and their Manage- ment. Present Status and Future Strategies (Sharma, G.,Y.S Mathur., Y.S. and Gupta, R.B.L. (eds). Agrobios, 5-37.

[2] Avise, J. C. (2000). Phylogeography: The history and formation of species. Harvard University Press, Cambridge. vii+453 p.

[3] Bhat, O.K., Bhat, A.A., Kaul, V.K. (2005). Faunistic studies of white grubs in Kashmir. Insect Environment, 11: 14- 15.

[4] Binneck,E., João Flávio Silva,V., Norman Neumaier, B., José Renato Farias and Alexandre Nep Omuceno, L. (2004). VSQual: a visual system to assist DNA sequencing quality control.Genetics and Molecular Research, 3 (4): 474-482.

[5] Blaxter. M.L. (2004). The promise of DNA Taxonomy. Proceedings of the Royal Society of America, Series B. 359: 669-679.

[6] Chandra, K. and Ahirwar, S.C. (2007). An inventory of scarab beetles (Coleoptera: Scarabaeidae) of AchanakmarAmarkantak biosphere re- serve, Chhattisgarh, India state Fauna Series. 15: 273-300.
[7] Chandra, K. and Singh, S.P. (2010) Scarabaeid beetles (Coleoptera) of Achanakmar Wildlife Sanctuary, Chhattisgarh. Nature Journal of Life Sciences, 7: 71-74.

[8] Chandra, K. and Gupta, D. (2011). Study of Scarabaeid beetles (Coleoptera) of Veerangana Durgavati Wildlife Sanctuary, Damoh, Madhya Pradesh, India. Deccan. Current Science, 5: 272-278.

[9] Chandra, K. and Gupta, D. (2012). Diversity and composition of dung beetles (Scarabaeidae: Scarabaeinae and Aphodiinae) assemblages in Sing- hori Wildlife Sanctuary, Raisen, Madhya Pradesh (India). International Journal of Science and Nature, 3: 886- 891.

[10] Dadmal, S.M., Khadakkar, S.S., Ghuge, P.A. (2013). Occurrence of five Holotrichia species (Coleoptera: Scarabaeidae: Melolonthinae) in Maharashtra and their male genitalia characterization. The BioScan, 8: 349-352.

[11] Dashad, S.S., Chauhan, R. and Choudhary, O.P. (2008). Emergence of differ- ent species of white grub beetles in relation to abiotic factors based on light trap catches. Research Crops, 9: 688.

[12] Dirk Ahrens., Michael,T., Monaghan and Alfried, P,V. (2007). DNA-based taxonomy for associating adults and larvae in multi-species assemblages of chafers (Coleoptera: Scarabaeidae). Moleclar Phylogenetics and Evolution, 44: 436-449.

[13] Dirk Ahrens., Scott, M. and Vogler, A.P. (2011). The phylogeny of monkey beetles based on mitochondrial and ribosomal RNA genes (Coleoptera: Scarabaeidae: Hopliini). Molecular Phylogeny and Evolution, 60: 408-415.

[14] Dittrich, G., Schröde, D.E., Conlong, M.J., Way, J. and Du. Harrison,G. (2009). Identification key to scarabaeid beetle larvae attacking sugarcane in South Africa using DNA barcoding and integrative taxonomy. Proceedings of South African Sugar Technolgists Association, 82: 500-524. 
[15] Dhoj, Y.G.C., Keller, S., Nagel, P. and Kafle, L. (2009). Abundance and diversity of scarabaeid beetles (Coleoptera: Scarabaeidae) in different farming areas of Nepal. Formosan Entomon, 29: 103-112

[16] Fang, X. M. (2009). Phylogenetic analysis of Chrysomelidae in China inferred from mitochondrial COI sequences (Coleoptera: Chrysomeloidea). Journal of Suzhou University, 24 (1): 113-117.

[17] Gavarāne, I. (2011). Inese Kokina, Kristīna Aksjuta, Arvīds Barševskis and Uldis Valainis, Acta Biologica Universitatis Daugavpiliensis. 2011, 11 (2): 141-145.

[18] Greenberg, B. (2002). Key to the eggs, larvae, pupae and adults of some forensically important flies, pp. 54-153. In: B. Greenberg \& J. C. Kunich (eds). Entomology and the law flies as forensic indicators. Cambridge University Press, Cambridge. xii+298 p.

[19] Gupta,D., Kailash Chandra and Salma Khan (2014). An updated checklist of scarabaeoid beetles (Coleoptera: Scarabaeoidea) of Pench Tiger Reserve, Madhya Pradesh, India. Journal of Entomology and Zoology Studies, 2(5): 225-240

[20] Hebert, P.D.N, Cywinska, A., Ball, S.L., and DeWaard, J.R. (2003). Biological identifications through DNA barcodes. Proceedings of Royal Society America, B. 270: 313-321.

[21] Imura,O., Morimoto,N. Shi, K. and Sasaki, H. (2014). Landscape diversity of pasture dung beetle communities in the central region of mainland Japan and implications for conservation management. Biodiversity and Conservation, 23: 597-616.

[22] Judith, A.S., and Nicola, C. B. (2008). Molecular genetic identification of forensically important flies in the UK. Forensic Science International: Genetics Supplement Series 1 (1): 620-622.

[23] Khanal, D., Dhoj, Y.G.C., Sporleder, M. and Thapa, R.B. (2012). Distribution of whitegrubs in here ecological domains of Nepal. The Journal of Agriculture and Environment, 13: 40-46.

[24] Lawerence, J.F., Hastings ,A.M., Dallwitz, M.J., Paine, T.A., Zurcher, E.J. (2013). Beetle Larvae of the World: Descriptions, Illustrations, and Information Retreival for Families and Subfamilies. CSIRO Publishing, Australia.

[25] Maryati, K.T. and Sugiyarto (2009). Characterization of white grub (Melolonthidae; Coleoptera) in salak plantation based on morphology and protein banding pattern. Bioscience 1 (2):7277

[26] Mgocheki,N., Conlong, D.E., Ganeshan, S. and Addison, P. (2012). Molecular identification of South African sugarcane white grubs (Coleoptera: Scarabaeidae). Proceedings of the South African Sugar Technologists' Association, 85: 108 113.

[27] Michael. M.T., Balke, Ryan Gregory and Alfried, P.V. (2005). DNA-based species delineation in tropical beetles using mitochondrial and nuclear markers. Philosophical Transactions of the Royal Society B: Biological Sciences, 360(1462): 1925-1933.

[28] Monti, M.M., Nappo, A.G. and Giorgini, M. (2005). Molecular characterization of closely related species in the parasitic genus Encarsia (Hymenoptera: Aphelinidae) based on the mitochondrial cytochrome oxidase subunit gene. Bulletin Entomological Research, 95: 401-408.

[29] Pathania ,M., Chandel, R.S., Verma, K.S. and Mehta, P.K. (2015). Studies on the Preliminary Ecology of Invasive Phytophagus Scarabaeidae of North Western Himalaya. Arthropods, 4: 46-68.

[30] Paul, F., Rugman, J., Robert, W., Tom, V.N., Richard, S. (2009). Molecular differentiation of the Psyttalia concolor (Szépligeti) species complex (Hymenoptera: Braconidae) associated with olive fly, Bactrocera oleae (Rossi) (Diptera: Tephritidae), in Africa. Biological Control ,49: 17-26.

[31] Qiu, B., Chen, Y.L., Liu, W., Peng, X., Li, M.Z. (2009). Identification of three major Bemisia tabaci biotypes in China based on morphological and DNA polymorphisms. Progress in Natural Science, 19: 713-718.

[32] Richards, N.K., Glare, T.R. and Hall, D.C.L. (1997). Genetic variation in grass grub, Costelytra zealandica, from several regions. Proceedings of 50th NewZealand Plant Protection Conference, 1997: 338-343.

[33] Singh, M.P., Bisht, R.S., and Mishra, P.N. (2003). Distribution of white Grub fauna in Garhwal Hills of Western Himalayas. Indian Journal of Entomology, 65: 217-221.

[34] Sharma, R.N., Mitra, B. and Chakraborty,P. (2004). Fauna of Protected Areas - 12: A preliminary account of beetle (Coleoptera) fauna of Kalatop-Khajjiar Wildlife Sanctuary, Himachal Pradesh. Zoo's Print Journal, 19: 1626.

[35]

[36] Stijin, D. and Matthias, G. (2009). COI sequence variability between Chrysomyinae of forensic interest. Forensic Science International: Genetics, 3 (2): 89-95.

[37] Tamura, K. and Nei, M. (1993). Estimation of the number of nucleotide substitutions in the control region of mitochondrial DNA in humans and chimpanzees.Molecular Biology and Evolution, 1993.10 (3):512-26.

[38] Tamura, K., Nei, M. and Kumar, S. (2004). Prospects for inferring very large phylogenies by using the neighbor-joining method. Proceedings of National Academy of Sciences (USA) ,101: 11030-11035.

[39] Tamura,T.,Peterson,D., Peterson, N., Stecher,G.,Nei,M. and Kumar, S. (2011). MEGA5: Molecular Evolutionary Genetics Analysis Using Maximum Likelihood, Evolutionary Distance, and Maximum Parsimony Methods. Molecular Biology and Evolution, 28(10):2731-2739.

[40] Tautz, D., Arctander, P., Minelli, A.H., Thomas, R. and Alfried, P.V. (2003). A Plea for DNA Taxonomy. Trends in Ecology and Evolution, 18: 70-74. 
[41] Thakare, V.G. and Zade, V.S. (2012). Diversity of beetles (Insecta: Coleoptera) from the vicinity of Semadoh - Makhala road, Sipnarange, Melghat Tiger Reserve, (MS) India. Bioscience, 3: 112-115.

[42] Theurkar, S.V., Ghadage, M.K., Madan, S.S., Bhor, G.L., and Patil, S.B. (2013). Occurrence of white grubs in ground nut Growing area of Khed Taluka, part of Northern Western Ghats. MS, India. Research Journal of Recent Sciences, 2: 13.

[43] Thompson, J.D., Higgins, D.G., Gibson, T.J. (1994). CLUSTAL W: improving the sensitivity of progressive multiple sequence alignment through sequence weighting, position-specific gap penalties and weight matrix choice. Nucleic Acids Reearch, 11: 4673-4680.

[44] Wardani, S.and Sugiyarto.(2009).Characterization of white grub (Melolonthidae; Coleoptera) in salak plantation based on morphology and protein banding pattern . Nusantara Bioscience, 1: 38-42.

[45] Wallman, J.F., Donnellan, S.C. (2001). The utility of mitochondrial DNA sequences for the identification of forensically important blowflies (Diptera: Calliphoridae) in southeastern Australia. Forensic Science International, 20(12):60-67.

[46] Wells, J. D., Sperling, F.(2001). DNA-based identification of forensically important Chrysomyinae (Diptera: Calliphoridae). Forensic Science International, 120 (1-2): 110-115.

[47] Williams, J.G.K., Kubelik, A.R., Livak,K.J., Rafalski, J.K. and Tingey, S.V. (1990). Nucleic Acids Research, 18: 65316535

[48] Zhu, Y.C.J., Burd, D., Elliott, N.C. and Greenstone, M.H. (2000). Specific ribo- somal DNA markers for early PCR detection of Aphelinus hordei (Hy- menoptera: Aphelinidae) and Aphidius colemani (Hymenoptera: Aphi- diidae) from Diuraphis noxia (Homoptera: Aphididae). Annals of Entomological Society of America, 93: 486-491.

[49] Zahoor, M.K, Suhail, A., Zahoor, S., Iqbal, A. and Awan, F.S. (2013). Molecular characterization of Scarab beetles (Scarabaeidae: Coleoptera) using RAPD. Pakistan Journal of Life Social Sciences, 11 (3): 238-243. 